\title{
Paper
}

\section{Properties and Characterization of Perovskite Related Oxides for Rapid $\mathrm{CO}_{2}$ Solidification}

\author{
Kiyoshi Nomura \\ School of Engineering, The University of Tokyo, 7-3-1 Hongo, Bunkyo-ku, Tokyo 113-8656, Japan.
}

Received July 31, 2003

\begin{abstract}
SYNOPSIS
Perovskite related oxides such as $(\mathrm{Ba}, \mathrm{Ca})(\mathrm{Fe}, \mathrm{Co}) \mathrm{O}_{3-\delta}(\mathrm{Sr}, \mathrm{Ca})(\mathrm{Fe}, \mathrm{Co}) \mathrm{O}_{3-\delta}$ and $(\mathrm{Ba}, \mathrm{Ca})(\mathrm{Fe}, \mathrm{Mg}) \mathrm{O}_{3-\delta}$ have been developed as safety materials for quick solidification of $\mathrm{CO}_{2}$ at high temperatures. The $\mathrm{CO}_{2}$ solidification properties and microstructures were investigated. Perovskite oxides $\left(\mathrm{ABO}_{3}\right)$ become active for $\mathrm{CO}_{2}$ accommodation due to the lattice distortion produced by mixing different alkaline earth ions in site $\mathrm{A}$ and the mixed valence states by substitution of $\mathrm{Fe}$ ions by $\mathrm{Co}$ and $\mathrm{Mg}$ ions in site $\mathrm{B}$. The mechanism of rapid $\mathrm{CO}_{2}$ accommodation was taken into consideration. KEYWORDS

Carbon dioxide gas solidification, mixed perovskite, brownmillerite, Mössbauer spectroscopy
\end{abstract}

\section{Introduction}

The accumulation of $\mathrm{CO}_{2}$ gas in the atmosphere causes the global warming as a green house effect. In Japan, the total amount of exhausted $\mathrm{CO}_{2}$ was $3.43 \times 10^{2} \mathrm{Mt}$ a year in 1994. The amount of $\mathrm{CO}_{2}$ emitted from industry was 1.36 $\times 10^{2} \mathrm{Mt}$, i.e. about $40 \%$ of the total emission ${ }^{1)}$. It is important to reduce the amount of exhausted $\mathrm{CO}_{2}$ before it diffuses into the air. So materials for direct and rapid solidification of $\mathrm{CO}_{2}$ emitted from industrial furnaces should be developed.

In the beginning of $1990 \mathrm{~s}^{2}$, we found that the mixed perovskite, $(\mathrm{Ba}, \mathrm{Ca})(\mathrm{Fe}, \mathrm{Co}) \mathrm{O}_{3-\delta}$, absorbs $\mathrm{CO}_{2}$ rapidly at high temperatures between 600 and $950{ }^{\circ} \mathrm{C}^{3,4)}$. The decomposition temperatures of $\mathrm{MgCO}_{3}, \mathrm{CaCO}_{3}, \mathrm{SrCO}_{3}$, and $\mathrm{BaCO}_{3}$ are $540^{\circ} \mathrm{C}, 898^{\circ} \mathrm{C}, 1150^{\circ} \mathrm{C}$, and $1350^{\circ} \mathrm{C}$, respectively. The control of the solidification and decomposition temperatures may be realized by substitutions in the perovskite lattice. From the tolerance factor of ionic radii for formation of cubic perovskite $\left(\mathrm{ABO}_{3}\right)$, it is expected that $\mathrm{Mg}^{2+}$ ions can substitute for $\mathrm{Fe}^{4+}$ ions at site $\mathrm{B}$ of the perovskite structure, whereas $\mathrm{Ba}^{2+}, \mathrm{Sr}^{2+}$, and/or $\mathrm{Ca}^{2+}$ ions occupy site A.

In this paper, the microenvironments of $\mathrm{Fe}$ in $(\mathrm{Ba}, \mathrm{Ca})$ $(\mathrm{Fe}, \mathrm{Co}) \mathrm{O}_{3-\delta}(\mathrm{Sr}, \mathrm{Ca})(\mathrm{Fe}, \mathrm{Co}) \mathrm{O}_{3-\delta}$ and $(\mathrm{Ba}, \mathrm{Ca})(\mathrm{Fe}, \mathrm{Mg}) \mathrm{O}_{3-\delta}$ mixed oxides were characterized from the view points of rapid $\mathrm{CO}_{2}$ accommodation mechanism at high temperature.

\section{Experimental}

The mixed oxides of $(\mathrm{Ba}, \mathrm{Ca})(\mathrm{Fe}, \mathrm{Co}) \mathrm{O}_{3-\delta},(\mathrm{Sr}, \mathrm{Ca})$ $(\mathrm{Fe}, \mathrm{Co}) \mathrm{O}_{3-\delta}$, and $(\mathrm{Ba}, \mathrm{Ca})(\mathrm{Fe}, \mathrm{Mg}) \mathrm{O}_{3-\delta}$ were prepared by simply mixing metal nitrates and carbonates with a shaker ball-mill for $30 \mathrm{~min}$, and heated at higher than $850^{\circ} \mathrm{C}$ for more than 10 hours in air. Alternatively, the mixed oxides were prepared by a sol-gel method using an ethylene glycol solution including metal nitrates and citric acid. The mixed solutions were stirred at $80^{\circ} \mathrm{C}$ and the solvent was evaporated at around $200^{\circ} \mathrm{C}$. The solid residue was preheated at $500^{\circ} \mathrm{C}$ for 2 hours and annealed at $850^{\circ} \mathrm{C}$ for 10 hours.

The $\mathrm{CO}_{2}$ solidification properties were measured at a heating rate of $20^{\circ} \mathrm{C} / \mathrm{min}$ by thermogravimetric analysis (TGA). The structures of mixed oxides were analyzed by $\mathrm{X}$-ray powder diffraction (XRD). The microenvironment of Fe species at site B was characterized by ${ }^{57} \mathrm{Fe}$ Mössbauer spectroscopy.

\section{Results}

\subsection{Absorption Properties}

$\mathrm{BaFeO}_{3-\delta}$ and $\mathrm{CaFeO}_{2.5}$ have no potential to absorb $\mathrm{CO}_{2}$ rapidly. However, $(\mathrm{Ba}, \mathrm{Ca})(\mathrm{Fe}, \mathrm{Co}) \mathrm{O}_{3-\delta}$ absorbs $\mathrm{CO}_{2}$ at temperatures higher than $700^{\circ} \mathrm{C}$ in air $+10 \% \mathrm{CO}_{2}$ atmosphere, and shows $46 \mathrm{~mol} \%$ absorption at $850^{\circ} \mathrm{C}^{3)}$. In the case of $\left(\mathrm{Ba}_{0.95} \mathrm{Ca}_{0.05}\right)\left(\mathrm{Fe}_{1-\mathrm{y}} \mathrm{Co}_{\mathrm{y}}\right) \mathrm{O}_{3-\delta}$ with $\mathrm{y}=0.2$, the weight increased in the temperature range between $600^{\circ} \mathrm{C}$ and $950^{\circ} \mathrm{C}$ and the maximum of $\mathrm{CO}_{2}$ absorption was $35 \mathrm{~mol} \%$, whereas 
with $\mathrm{y}=0.8$, the weight increased quickly from $550^{\circ} \mathrm{C}$ and reached $51 \mathrm{~mol} \%$ at $800^{\circ} \mathrm{C}$. Co rich oxides were more active for $\mathrm{CO}_{2}$ absorption than $\mathrm{Fe}$ rich oxides.

The mixed oxides $\left(\mathrm{Sr}_{1-\mathrm{x}} \mathrm{Ca}_{\mathbf{x}}\right)\left(\mathrm{Fe}_{1-\mathrm{y}} \mathrm{Co}_{\mathrm{y}}\right) \mathrm{O}_{3-\delta}$ showed rapid absorption of $\mathrm{CO}_{2}$ in the temperature range from $550^{\circ} \mathrm{C}$ to $850^{\circ} \mathrm{C}$. The substitution of $\mathrm{Sr}$ by a half mole of $\mathrm{Ca}$ and of $\mathrm{Fe}$ by a half mole of Co provided rapid absorption of $\mathrm{CO}_{2}$, whereas the temperature of maximum $\mathrm{CO}_{2}$ absorption decreased from $850^{\circ} \mathrm{C}$ to $780^{\circ} \mathrm{C}$ with the increase of $\mathrm{Ca}$ contents. Comparing $\mathrm{Ba}(\mathrm{Fe}, \mathrm{Co}) \mathrm{O}_{3-\delta}$ and $\mathrm{Sr}(\mathrm{Fe}, \mathrm{Co}) \mathrm{O}_{3-\delta}$ with the same substitution level of $\mathrm{Ca}$, one finds that $\mathrm{Ba}$ mixed oxides were more active than $\mathrm{Sr}$ mixed oxides. Moreover, the decomposition temperature was higher for the $\mathrm{Ba}$ compounds by about $100^{\circ} \mathrm{C}$.

$\left(\mathrm{Ba}_{1-\mathrm{x}} \mathrm{Ca}_{\mathrm{x}}\right)\left(\mathrm{Fe}_{1-\mathrm{y}} \mathrm{Mg}_{\mathrm{y}}\right) \mathrm{O}_{3-\delta}(\mathrm{x}=0.5,0.95$, and $\mathrm{y}=0.2,0.5$, 0.8 ) showed high activity for $\mathrm{CO}_{2}$ absorption, namely, from $32 \mathrm{~mol} \%$ to $55 \mathrm{~mol} \%$ at $850^{\circ} \mathrm{C}^{5}$. The $\mathrm{Mg}$ mixed oxides with equal $\mathrm{Ba}$ and $\mathrm{Ca}$ contents started to absorb $\mathrm{CO}_{2}$ gas at around $350^{\circ} \mathrm{C}$, and released above the $890^{\circ} \mathrm{C}$. The starting and releasing temperatures of $\mathrm{CO}_{2}$ absorption were determined by the $\mathrm{Mg} / \mathrm{Fe}$ ratio, and by the $\mathrm{Ba} / \mathrm{Ca}$ ratio, respectively. The decomposition of $\mathrm{Ca}$-rich perovskite absorbed with $\mathrm{CO}_{2}$ started at around $900{ }^{\circ} \mathrm{C}$, which corresponds to the decomposition temperature of $\mathrm{CaCO}_{3}$, whereas all oxides with $\mathrm{Ba} / \mathrm{Ca}=1$ released $\mathrm{CO}_{2}$ rapidly around $1070^{\circ} \mathrm{C}$. The $\mathrm{Mg}$ ions were not isolated as $\mathrm{MgCO}_{3}$ in the $\mathrm{CO}_{2}$-treated materials since the decomposition temperature of $\mathrm{MgCO}_{3}$ is $540^{\circ} \mathrm{C}$. The lattice oxygen of these oxides was easily released by endothermic reaction in air around $420^{\circ} \mathrm{C}$, while the $\mathrm{CO}_{2}$ absorption began at the same temperature as shown in Fig. 1. It is considered that good oxygen permeability is necessary for quick absorption or solidification of $\mathrm{CO}_{2}$.

A mechanical treatment by ball milling were studied for $\mathrm{CO}_{2}$ absorption using $\left(\mathrm{Sr}_{1-\mathrm{x}} \mathrm{Ca}_{\mathbf{x}}\right)\left(\mathrm{Fe}_{0.5} \mathrm{Co}_{0.5}\right) \mathrm{O}_{3-\delta}$ with $\mathrm{x}=0.05$

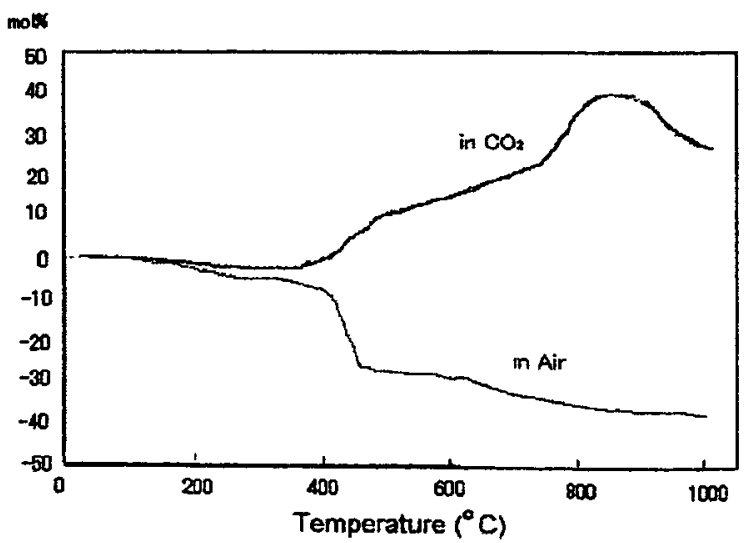

Fig.1 Typical TGA curves of $\left(\mathrm{Ba}_{1-\mathrm{x}} \mathrm{Ca}_{x}\right)\left(\mathrm{Fe}_{1-\mathrm{y}} \mathrm{Mg}_{\mathrm{y}}\right)$ oxides in $\mathrm{CO}_{2}$ and in air. (not so active for $\mathrm{CO}_{2}$ absorption) and $\mathrm{x}=0.5$ (active for $\mathrm{CO}_{2}$ absorption $)^{6}$. The ball milling of $\left(\mathrm{Sr}_{0.95} \mathrm{Ca}_{0.05}\right)\left(\mathrm{Fe}_{0.5} \mathrm{Co}_{0.5}\right)$ $\mathrm{O}_{3-\delta}$ for 5 minutes increased the absorption capacity of $\mathrm{CO}_{2}$ from $10 \mathrm{~mol} \%$ to $39 \mathrm{~mol} \%$ and the starting temperature of $\mathrm{CO}_{2}$ absorption decreased from $650^{\circ} \mathrm{C}$ to $510^{\circ} \mathrm{C}$. A ball milling for $5 \mathrm{~min}$ improved the absorption properties, but a ball milling for a long time decreased the potential for $\mathrm{CO}_{2}$ absorption. It is considered that necks between the grains appeared at the beginning of the ball milling, and that the surface area increased. The milling for a long time was considered to affect the structure of crystals such as deformation, defects and grain size. These suggest that not only the surface of the oxide grains but also the bulk structure is crucial for the $\mathrm{CO}_{2}$ absorption.

$\left(\mathrm{Ba}_{0.5} \mathrm{Ca}_{0.5}\right)\left(\mathrm{Fe}_{0.8} \mathrm{Mg}_{0.2}\right) \mathrm{O}_{3-\delta}$ was measured by TGA in $\mathrm{CO}_{2}$ atmosphere. The weight gains due to $\mathrm{CO}_{2}$ absorption before and after ball milling for $5 \mathrm{~min}$ were $34 \mathrm{~mol} \%$, and $38 \mathrm{~mol} \%$, respectively, and the starting temperature decreased from $600^{\circ} \mathrm{C}$ to $410^{\circ} \mathrm{C}$ after ball milling.

\subsection{Characterizations of oxides}

$\left(\mathrm{Ba}_{0.95} \mathrm{Ca}_{0.05}\right)\left(\mathrm{Fe}_{1-\mathrm{y}} \mathrm{Co}_{y}\right) \mathrm{O}_{3-\delta}$ with $\mathrm{y}<0.6$ showed cubic structures ( $a=0.4030-0.4083 \mathrm{~nm}$ ), and became orthorhombic like $\mathrm{BaCoO}_{2.93}$ with increasing Co contents.

$\left(\mathrm{Sr}_{1-\mathrm{x}} \mathrm{Ca}_{\mathbf{x}}\right)\left(\mathrm{Fe}_{0.5} \mathrm{Co}_{0.5}\right) \mathrm{O}_{3-\delta}(\mathrm{x}=0.05$ and $\mathrm{x}=0.5)$ showed cubic structure ( $a=0.3862 \mathrm{~nm}$ ) and orthorhombic structure $(a=0.5576, b=1.536, c=0.5419 \mathrm{~nm})$, respectively. The oxygen deficiencies increased with Ca contents.

The lattice parameters of the cubic $(\mathrm{Ba}, \mathrm{Ca})(\mathrm{Fe}, \mathrm{Mg}) \mathrm{O}_{3-\delta}$ increased with temperature, whereas, in the orthorhombic structure with more oxygen defects, the lattice parameter of $b$ increased with temperature drastically as compared with the behavior of $a$ and $c$.

In $\mathrm{ABO}_{3-\delta}$, one tetrahedron and two octahedra are produced at site $B$ in a random or ordered distribution when $\delta=1 / \mathrm{n}$ and $\mathrm{n}=3$, and layered structures of tetrahedra and octahedra are produced when $n=2$. The latter corresponds to the brownmillerite structure. When one oxygen atom releases from the cubic perovskite, two octahedral $\mathrm{Fe}^{\mathrm{IV}}$ species become two $\mathrm{Fe}^{\mathrm{III}}$ species; one with tetrahedral, the other with octahedral coordination. If the tetrahedra and octahedra are ordered, two sextets due to ferrimagnetism appear in the Mössbauer spectrum, whereas $\mathrm{Fe}^{\mathrm{IV}}$ species in octahedron show a singlet or a doublet due to paramagnetic behavior, depending on the electron configuration around

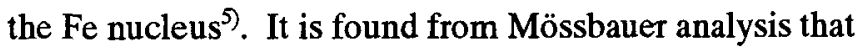
the line widths of the mixed oxides are broad, and that $\mathrm{Fe}$ atoms prefer octahedral sites $\left(B_{i n}=48.5 \mathrm{~T}\right)$, whereas Co atoms prefer tetrahedral sites $\left(B_{\text {in }}=40.1 \mathrm{~T}\right)$.

3.3 Characterization of the mixed oxides absorbed with $\mathrm{CO}_{2}$ 
In $\left(\mathrm{Ba}_{0.95} \mathrm{Ca}_{0.05}\right)\left(\mathrm{Fe}_{0.9} \mathrm{Co}_{0.1}\right) \mathrm{O}_{3-\delta} \delta^{4)}$, the paramagnetic peaks changed into two magnetic sextets $\left(B_{i n}=41.4 \mathrm{~T}\right.$, and 50.4 T) upon $\mathrm{CO}_{2}$ accommodation, and an additional new sextet with $B_{\text {in }}=47.5 \mathrm{~T}$ appeared on further $\mathrm{CO}_{2}$ absorption. The formers were similar to those due to oxygen defect structures. The latter could correspond to a spinel like $\mathrm{BaFe}_{2} \mathrm{O}_{4}$.

In the case of $\left(\mathrm{Sr}_{0.5} \mathrm{Ca}_{0.5}\right)\left(\mathrm{Fe}_{0.5} \mathrm{Co}_{0.5}\right) \mathrm{O}_{3-\delta}$ after $\mathrm{CO}_{2}$ absorption, the doublets disappeared and a new sextet of magnetic $\mathrm{Fe}^{\mathrm{III}}$ species was also observed together with a pair of sextets of the tetrahedral and octahedral sites ${ }^{8)}$. The intensity of the new sextet due to spinel increased with the $\mathrm{CO}_{2}$ solidification.

In the case of $\left(\mathrm{Ba}_{0.5} \mathrm{Ca}_{0.5}\right)\left(\mathrm{Fe}_{0.5} \mathrm{Mg}_{0.5}\right) \mathrm{O}_{3-\delta}$, paramagnetic $\mathrm{Fe}^{\mathrm{III}}(\delta=0.29 \mathrm{~mm} / \mathrm{s}, \Delta=0.85 \mathrm{~mm} / \mathrm{s}$, Area Int. $=62 \%)$ and $\mathrm{Fe}^{\mathrm{IV}}(\delta=-0.09 \mathrm{~mm} / \mathrm{s}, \Delta=0.84 \mathrm{~mm} / \mathrm{s}$, Area Int. $=38 \%)$ were produced after $\mathrm{CO}_{2}$ absorption. The valence state of $\mathrm{Mg}^{2+}$ ions is stable, and, from the population ratio of $\mathrm{Fe}^{\mathrm{III}}$ and $\mathrm{Fe}^{\mathrm{IV}}$ doublets, we conclude that only a part of the $\mathrm{Mg}$ ions is built in the perovskite lattice, and that the rest is present as $\mathrm{MgO}-\mathrm{CaO}$. Distorted structures are produced around $\mathrm{Fe}^{\mathrm{III}}$ atoms by $\mathrm{CO}_{2}$ accommodation, and $\mathrm{Mg}$ ions are removed from the perovskite lattice. When the sample absorbed $41 \mathrm{~mol} \% \mathrm{CO}_{2}$, a pair of sextet due to octahedral $\left(H_{\text {in }}=48.0 \mathrm{~T}, \delta=0.21 \mathrm{~mm} / \mathrm{s}, \Delta=-0.24 \mathrm{~mm} / \mathrm{s}\right)$ and tetrahedral $\left(H_{\text {in }}=43.7 \mathrm{~T}, \delta=0.21 \mathrm{~mm} / \mathrm{s}, \Delta=-0.31 \mathrm{~mm} / \mathrm{s}\right) \mathrm{Fe}^{\mathrm{II}}$ species appeared in the Mössbauer spectra. $B_{\text {in }}$ for the octahedral coordinated species was affected by large amounts of accommodated $\mathrm{CO}_{2}$. However, when the sample was heated at $1000^{\circ} \mathrm{C}$, the pair of sextets had more distinct parameters between octahedral sites $\left(B_{\text {in }}=51 \mathrm{~T}, \delta=0.36\right.$ $\mathrm{mm} / \mathrm{s}, 2 \varepsilon=0.57 \mathrm{~mm} / \mathrm{s})$, and tetrahedral sites $\left(B_{i n}=43.2 \mathrm{~T}\right.$, $\delta=0.19 \mathrm{~mm} / \mathrm{s}$, and $2 \varepsilon=-0.73 \mathrm{~mm} / \mathrm{s}$ ). In addition, a new sextet with $B_{\text {in }}=48 \mathrm{~T}$ was observed, due to a spinel type compound such as $\mathrm{MgFe}_{2} \mathrm{O}_{4}$ and/or $(\mathrm{Ba}, \mathrm{Ca}) \mathrm{Fe}_{2} \mathrm{O}_{4}$.

The hyperfine fields of the $\mathrm{Mg}$ mixed oxides were larger than those of Co mixed perovskites. The peak intensity corresponding to tetrahedral $\mathrm{Fe}^{\mathrm{III}}$ species was a little larger than that of octahedral sites. It shows that $\mathrm{Mg}$ ions favor to occupy the octahedral site. In the case of Fe and Co mixed perovskite, $\mathrm{Fe}$ and $\mathrm{Co}$ ions prefer the octahedral and tetrahedral sites, respectively.

The oxygen permeability in $\left(\mathrm{La}_{0.6} \mathrm{~A}^{\prime}{ }_{0.4}\right)(\mathrm{Fe}, \mathrm{Co}) \mathrm{O}_{3}{ }^{9}$ became large in the order of $\mathrm{A}^{\prime}=\mathrm{Ba}, \mathrm{Ca}$, and $\mathrm{Sr}$. It is considered to be due to the lattice distortion on the basis of difference of ionic radii between $\mathrm{La}^{3+}$ (ionic radius: $0.118 \mathrm{~nm}$ ) and alkaline earth metals (ionic radius: $\mathrm{Ba}^{2+}=0.136 \mathrm{~nm}, \mathrm{Sr}^{2+}=0.116 \mathrm{~nm}$, $\left.\mathrm{Ca}^{2+}=0.099 \mathrm{~nm}\right)$. The oxygen permeability may be the important precondition for $\mathrm{CO}_{2}$ uptake in the mixed oxides. The excess oxygen and alkaline earth ions in the brown- millerite thus play an important role in $\mathrm{CO}_{2}$ solidification.

\section{Conclusions}

The Co ions in $(\mathrm{Sr}, \mathrm{Ca})(\mathrm{Fe}, \mathrm{Co}) \mathrm{O}_{3-\delta}$ prefer to occupy the tetrahedral site as +3 valence state. A small portion of $\mathrm{Mg}$ ions occupy the octahedral site of $(\mathrm{Ba}, \mathrm{Ca})(\mathrm{Fe}, \mathrm{Mg}) \mathrm{O}_{3-\delta}$ oxides although the excess $\mathrm{Mg}$ ions are present as $\mathrm{CaO}$ $\mathrm{MgO}$ mixed oxides in the perovskite structure. The mixed perovskites with distortion at site $A$ and different valence states of metal ions at site $\mathrm{B}$ are active for $\mathrm{CO}_{2}$ solidification at high temperatures. $\mathrm{CO}_{2}$ is quickly accommodated as carbonate in the microstructure of $\left(\mathrm{AA}^{\prime}\right)\left(\mathrm{BB}^{\prime}\right) \mathrm{O}_{2.5}$ due to good oxygen permeability. The maximum amount of quickly accommodated $\mathrm{CO}_{2}$ is at largest half mole of the original perovskite, and the mixed perovskite oxides are decomposed into brownmillerite as bone structure, spinel compounds, and $\mathrm{Ba}, \mathrm{Sr}, \mathrm{Ca}$ or $\mathrm{Mg}$ carbonates.

The mixed oxides for $\mathrm{CO}_{2}$ solidification should be selected on the basis of the various purposes of reuse, storage, disposal, and conversion to another materials. The perovskite oxides aged can simply be activated by ball milling for several minutes. The modified perovskites are useful for direct and rapid $\mathrm{CO}_{2}$ solidifications at high temperatures.

\section{Acknowledgament}

Author expresses the thanks to Prof. Z. Homonnay, Eötvös Loránd University for cooperation and discussions.

\section{References}

1) Environment Congress for Asia and the Pacific (ECO Asia'96).

2) K.Nomura, T.Hayakawa, K.Takehira and Y.Ujihira: Apply. Catal. A, 101(1993)63.

3) K.Nomura, Y.Ujihira, T.Hayakawa and K.Takehira: Appl. Catal. A, 137(1996)25.

4) Z.Homonnay, K.Nomura, G.Juhász, A.Vértes and Y.Ujihira: J. Radioanal. Nucl. Chem., 239(1998)291.

5) K.Nomura, S.Kobayashi, K.Hashimoto, Ts.Sawada, Z.Homonnay and A.Vértes: J. Radioanal. Nucl. Chem., 255(2003)5183.

6) K.Nomura, Z.Homonnay, G.Juhász, A.Vértes, H.Donen and Ts.Sawada: Hyperfine Interactions, 139(2002)297.

7) K.Nomura, K.Tokumitu, T.Hayakawa and Z.Homonnay: J. Radioanal. Nucl. Chem. Articles, 246(2000)69.

8) G.Juhász, Z.Homonnay, K.Nomura and T.Hayakawa: A.Vértes, Solid State Ionics, 139(2001)219.

9) Y.Teraoka, T.Nobunaga and N.Yamasoe: Chem. Letter, (1988)503. 